\title{
Corrosion behaviour of metal inserts in simulated ancient masonry mortars
}

\author{
Maddalena Carsana ${ }^{\mathrm{a}, *}$, Eleonora Marra ${ }^{\mathrm{b}}$, Luca Bertolini ${ }^{\mathrm{a}}$ \\ a Politecnico di Milano, Department of Chemistry, Materials and Chemical Engineering “Giulio Natta”, via Mancinelli 7, 20131 Milano, Italy \\ ${ }^{\mathrm{b}}$ Fraunhofer Institute for Building Physics IBP, Holzkirchen Branch, Fraunhoferstr. 10, 83626 Valley, Germany
}

\section{H I G H L I G H T S}

- Corrosion of metal inserts in aerial and hydraulic mortars was studied.

- Carbon steel, stainless steel and titanium inserts were considered.

- Mortar composition had a secondary effect on the corrosion rate compared to the role of moisture.

- High corrosion rate was measured only for carbon steel in mortars exposed to 95\% RH or water suction.

- Mortar resistivity was found to be a reliable parameter to assess corrosion of embedded inserts.

\section{A R T I C L E I N F O}

\section{Article history:}

Received 24 December 2014

Received in revised form 17 June 2015

Accepted 14 July 2015

\section{Keywords:}

Metal insert

Corrosion

Mortar

$\mathrm{pH}$

Relative humidity

Temperature

Electrical resistivity

\begin{abstract}
A B S T R A C T
Corrosion of metal inserts may be detrimental to the durability of masonry. The paper discusses corrosion of carbon steel, stainless steel and titanium embedded in aerial and hydraulic mortars simulating those of ancient walls. The effects of temperature $\left(5-40{ }^{\circ} \mathrm{C}\right)$, moisture $(65-95 \% \mathrm{RH}$ and water suction) and electrical resistivity of mortars on the corrosion of metal inserts are discussed. Results showed that the corrosion rate of embedded steel, regardless of the mortar composition, is negligible in mortars exposed to $65-80 \% \mathrm{RH}$ (even at $40^{\circ} \mathrm{C}$ ) and modest even at $95 \% \mathrm{RH}$, while high values were obtained in the presence of water uptake.
\end{abstract}

(c) 2015 Elsevier Ltd. All rights reserved.

\section{Introduction}

Metal elements are often present in ancient masonry, either due to an original design choice or as the result of later restoration works. The use of these metal elements may have different purposes (Fig. 1), e.g. improving the structural behaviour of buildings (chains and ties) or preventing the propagation of cracks, and they may be applied externally or embedded in the materials of the masonry (mortar, bricks, stone blocks, etc.). In the latter case, the presence of these inserts may be harmful for the durability of masonry, since their corrosion may produce deleterious expansive phenomena leading to the failure of the brittle porous materials in which they are embedded [1-11].

\footnotetext{
* Corresponding author.

E-mail addresses: maddalena.carsana@polimi.it (M. Carsana), eleonora.marra@ ibp.fraunhofer.de (E. Marra), luca.bertolini@polimi.it (L. Bertolini).
}

It is relevant to make a distinction between metal inserts dated to the erection of the original structure, normally embedded in the structural elements, and those applied later during restoration phases (most often bonded externally). While externally applied metal elements are directly exposed to the action of the atmosphere (either inside or outside the building), those embedded in the masonry may have a complex corrosion behaviour, which not only depends on the type of metal insert but also on the materials with which they are in contact (e.g. hydraulic mortars, gypsum or bricks) and their moisture content.

Corrosion is an electrochemical process which takes place in the presence of water (and usually oxygen), through an electrochemical mechanism [1], as depicted in Fig. 2.

Fig. 2a shows that the moisture present in the pores of the mor$\operatorname{tar}$ (as well as of stone or burnt-clay blocks) is the electrolyte that allows corrosion of the metal insert, promoting the formation of expansive oxides that may eventually crack the masonry material. 

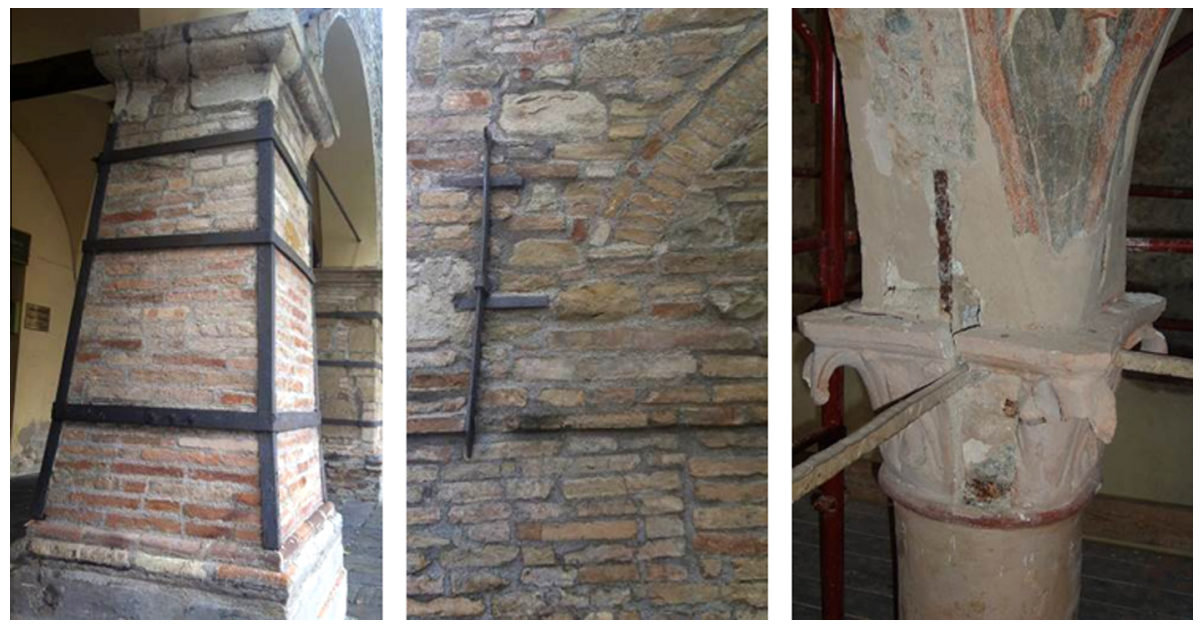

Fig. 1. Examples of use of metal inserts in cultural heritage buildings.

a
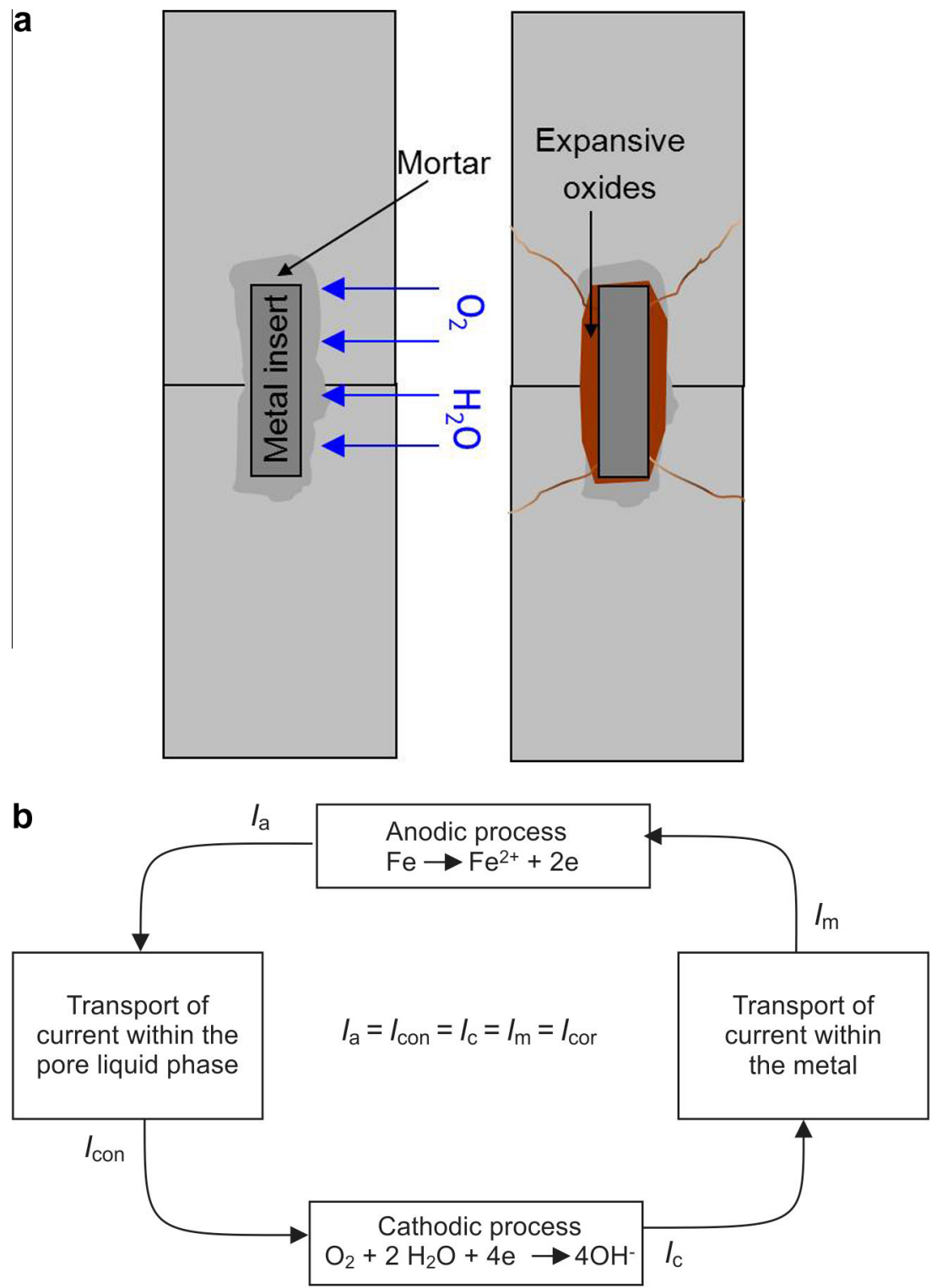

Fig. 2. Schematic representation of the corrosion process of a steel insert in masonry (a) and electrochemical mechanism (b) 
Fig. $2 \mathrm{~b}$ shows the four partial processes that determine the electrochemical mechanisms of corrosion of steel in masonry:

- the oxidation of iron (anodic process: $\mathrm{Fe} \rightarrow \mathrm{Fe}^{2+}+2 e$ ) produces iron ions and liberates electrons in the metal phase (dissolved $\mathrm{Fe}^{2+}$ ions may subsequently produce oxides or hydroxides giving rise to rust layers),

- the reduction of oxygen is the usual cathodic process $\left(\mathrm{O}_{2}+2 \mathrm{H}_{2} \mathrm{O}+4 e \rightarrow 4 \mathrm{OH}^{-}\right)$which consumes electrons and produces alkalinity,

- the transport of electrons occurs within the metal phase,

- finally the flow of electric current inside the pores of the masonry materials from the anodic regions to the cathodic ones is determined by transport of ions dissolved in the pore liquid phase. Therefore, moisture present in the porous masonry materials, besides promoting degradation of the masonry itself [11-13], may sustain the corrosion process of embedded metals.

These four processes occur at the same rate, which is the rate of the overall corrosion process $\left(i_{\text {corr }}\right)$. The corrosion rate will thus be determined by the slowest of the four partial processes $[1,2]$. The anodic reaction will usually be the (slowest) controlling process when the metal is passive; this occurs for unalloyed steel when it is in contact with alkaline (non-carbonated) mortars. The rate of the cathodic reaction depends on oxygen availability and it may be the controlling process when there is lack of oxygen, e.g. when the pores are permanently saturated with water. The rate of the transport of current through the pores of the masonry materials depends on the pore microstructure, the moisture content and the composition of the liquid phase in the pores. This could be the controlling process (ohmic control) when the electrical resistivity of the porous materials is high, as may occur in dry environments due to lack of water inside the pores.

Consequently, a large number of parameters, related to both the environment and the materials, will play a complex role, which makes prediction of the actual corrosion rate of metal inserts quite difficult.

As a matter of fact, the study of the dependence of the corrosion rate of embedded metal inserts on the environmental conditions is a subject of great interest in relation to optimising restoration methods and promoting a durable approach for the preservation of buildings. Improving the understanding of corrosion of metals embedded in masonry could provide a tool for the design of repair works which are not merely aimed at the remediation of corrosion damages (e.g. cracking), but also at the control of corrosion propagation. This is a pre-requisite to fulfil conservation requirements by preserving the original materials as much as possible.

Although corrosion of steel in concrete has been extensively studied and a great deal of information is available [14-16] and several papers can be found that deal with the characterisation of materials (both metallic insert and masonry mortars) collected from historical buildings [17-22], there is a significant lack of information about the corrosion behaviour of metal inserts.

This paper describes the results of a study aimed at the evaluation of the corrosion behaviour of different metals (carbon steel, stainless steel and titanium) embedded in mortars made with several types of binder (gypsum or blends of gypsum-lime, lime-pozzolana and lime-cocciopesto). The effect of different conditions, in terms of temperature $\left(5-40^{\circ} \mathrm{C}\right)$ and relative humidity $(65-95 \% \mathrm{RH}$ and water uptake) on corrosion rate of metal inserts is discussed. Parameters that could be considered for the monitoring of corrosion behaviour of metal inserts in ancient masonries are also addressed.

\section{Experimental study}

Tests were carried out on mortars made with gypsum $(G)$, lime and gypsum $(L G)$ and blended lime with two different types of hydraulic additions: natura pozzolana, $L P$ [23] and cocciopesto, $L C P$ (which was obtained by mixing lime and grounded ancient bricks). Mix proportions and main properties of the mortars are presented in Table 1. A mortar with a blend of lime and Portland-limestone cement (CEM II/A-L 42.5) and the same water/binder/aggregate ratio of $L P$ and $L C P$ was also cast $(L C)$, simulating a modern mortar. Mortar composition was designed in order to obtain in the fresh state a consistence of about $50 \%$ measured using a flow table test, according to EN 1015-3 standard. Actual values of consistence varied in the range of 43-57\%.

The 28-day compressive strength measured on $40 \times 40 \times 160 \mathrm{~mm}^{3}$ prisms was 10.2-13.9 MPa for mortars based on gypsum while for lime-pozzolana and limecocciopesto blends it was about $1 \mathrm{MPa}$. More details of the properties of the mortars in the hardened state are reported in Ref. [8].

The corrosion behaviour of metals embedded in the above mortars was studied on $80 \times 90 \times 30 \mathrm{~mm}^{3}$ reinforced prisms (Fig. 3), containing two bars $(6 \mathrm{~mm}$ in diameter) of carbon steel (cover depth was $12 \mathrm{~mm}$ ). A low carbon steel [8] with ferritic microstructure was used in order to simulate common ancient steels $[7,17,18]$. Specimens with stainless steel AISI 304L and titanium smooth bars were also prepared to test the corrosion behaviour of these metals often used in restoration works.

Reinforced specimens were cast in PVC moulds and demoulded after 5 days. All specimens were cured for 28 days overall in a climatic chamber at $20^{\circ} \mathrm{C}$ ( 7 days at $95 \% \mathrm{RH}$ and 21 days at $65 \% \mathrm{RH}$ ). Two wires ( $2 \mathrm{~mm}$ in diameter) of stainless steel (AISI 304L) were also embedded in the specimens and used as counter-electrodes for corrosion rate and resistivity measurements.

At the end of curing, each reinforced specimen was placed in a carbonation chamber with $4 \% \mathrm{CO}_{2}$ and $65-70 \% \mathrm{RH}$ until the complete specimen was fully carbonated. This occurred within a month for all types of mortar. The penetration of the carbonation front was measured on parallel non-reinforced specimens by means of $\mathrm{pH}$ indicators (phenolphthalein test). $\mathrm{pH}$ of the pore solution was also investigated by mixing in 1:1 proportion $\mathrm{CO}_{2}$-free distilled water with the powder obtained by grinding samples collected from the studied mortars (both before and after accelerated carbonation).

After the exposure in the carbonation chamber, reinforced specimens were exposed to different environments, by varying the relative humidity (65-80-95\% $\mathrm{RH})$ and the temperature $\left(5-20-40^{\circ} \mathrm{C}\right)$. The corrosion potential of metal inserts $\left(E_{\text {corr }}, \mathrm{mV}\right.$ ) was measured versus a $\mathrm{Ag} / \mathrm{AgCl}$ reference electrode placed on the surface of the specimen through a wet sponge. Corrosion rate $\left(i_{\text {corr }}, \mathrm{mA} / \mathrm{m}^{2}\right)$ was measured through the polarisation resistance method by applying a potential shift of $\Delta E= \pm 10 \mathrm{mV}$ vs $E_{\text {corr }}$ (first anodic, then cathodic) and measuring the flowing current $i$ after $30 \mathrm{~s}$. The corrosion rate was calculated as: $i_{\text {corr }}=B /(\Delta E / i)$, considering $B=26 \mathrm{mV}$.

The two parallel stainless steel wires of each specimen were used for monitoring the electrical resistivity of the mortar $(\rho, \Omega \mathrm{m})$. Electrical conductance of the mortar between the two wires $(G, \mathrm{mS})$ was measured with a conductivity meter and converted into electrical resistivity $(\rho, \Omega \mathrm{m})$ by using the relationship: $\rho=K / G$ (where the cell constant $K=42.4 \mathrm{~m}^{-1}$ was determined with a FEM model).

Fig. 4 shows, as an example, the corrosion potential (Fig. $4 \mathrm{~b}$ ) and corrosion rate (Fig. 4a) of two replicate carbon steel bars (indicated in the graph respectively as a and b) and the electrical resistivity of mortar of a specimen (Fig. 4c) made with lime-gypsum blend mortar $(L G)$, as a function of time during exposure to a sequence of three moisture conditions (65-80-95\% RH) at $20{ }^{\circ} \mathrm{C}$.

After carbonation, this specimen was initially maintained for about 50 days at $65 \% \mathrm{RH}$ during which steady values of $-220 \mathrm{mV} \mathrm{vs} \mathrm{Ag} / \mathrm{AgCl}$ and $0.01 \mathrm{~mA} / \mathrm{m}^{2}$ (corresponding to about $0.01 \mu \mathrm{m} /$ year of average penetration rate) were measured for $E_{\text {corr }}$ and $i_{\text {corr }}$, respectively. The two replicate bars showed a well reproducible behaviour. In this dry condition the electrical resistivity of the mortar was rather high (exceeding $10^{4} \Omega \mathrm{m}$ ). Subsequently the relative humidity of the chamber was increased to $80 \%$ for another 50 days and then to $95 \%$ for another 50 days. After the imposed changes in humidity, within a few days the steel bars reached steady

Table 1

Mix proportions and main properties of the mortars prepared in the laboratory. Legend: $w / b / a g g=$ water-binder-aggregate ratios.

\begin{tabular}{|c|c|c|c|c|}
\hline \multirow{2}{*}{$\begin{array}{l}\text { Binder type } \\
\text { Mixture acronymic }\end{array}$} & \multicolumn{2}{|c|}{ Gypsum mortars } & \multicolumn{2}{|c|}{ Lime mortars } \\
\hline & G & $L G$ & $L P$ & $L C P$ \\
\hline $\begin{array}{l}\text { Water/binder/aggregate } \\
\qquad(w / b / a g g)\end{array}$ & $0.42 / 1 /-$ & $0.63 / 1 / 1.2$ & $1.05 / 1 / 3.01$ & $1.05 / 1 / 3.01$ \\
\hline Water $\left(\mathrm{kg} / \mathrm{m}^{3}\right)$ & 515 & 404 & 402 & 402 \\
\hline Sand $\left(\mathrm{kg} / \mathrm{m}^{3}\right)$ & - & 769 & 1148 & 1148 \\
\hline Lime $\left(\mathrm{kg} / \mathrm{m}^{3}\right)$ & - & 212 & 191 & 191 \\
\hline Gypsum $\left(\mathrm{kg} / \mathrm{m}^{3}\right)$ & 1227 & 430 & - & - \\
\hline Pozzolana $\left(\mathrm{kg} / \mathrm{m}^{3}\right)$ & - & - & 191 & - \\
\hline Cocciopesto $\left(\mathrm{kg} / \mathrm{m}^{3}\right)$ & $-‘$ & - & - & 191 \\
\hline Portland cement $\left(\mathrm{kg} / \mathrm{m}^{3}\right)$ & - & - & - & - \\
\hline Consistence (\%) & 55.0 & 42.5 & 56.9 & 53.1 \\
\hline $\mathrm{R}_{\mathrm{c}, 28 \mathrm{gg}}(\mathrm{MPa})$ & 13.91 & 10.24 & 0.94 & 0.77 \\
\hline Density $_{28 \mathrm{gg}}\left(\mathrm{kg} / \mathrm{m}^{3}\right)$ & 1442 & 1619 & 1614 & 1526 \\
\hline
\end{tabular}




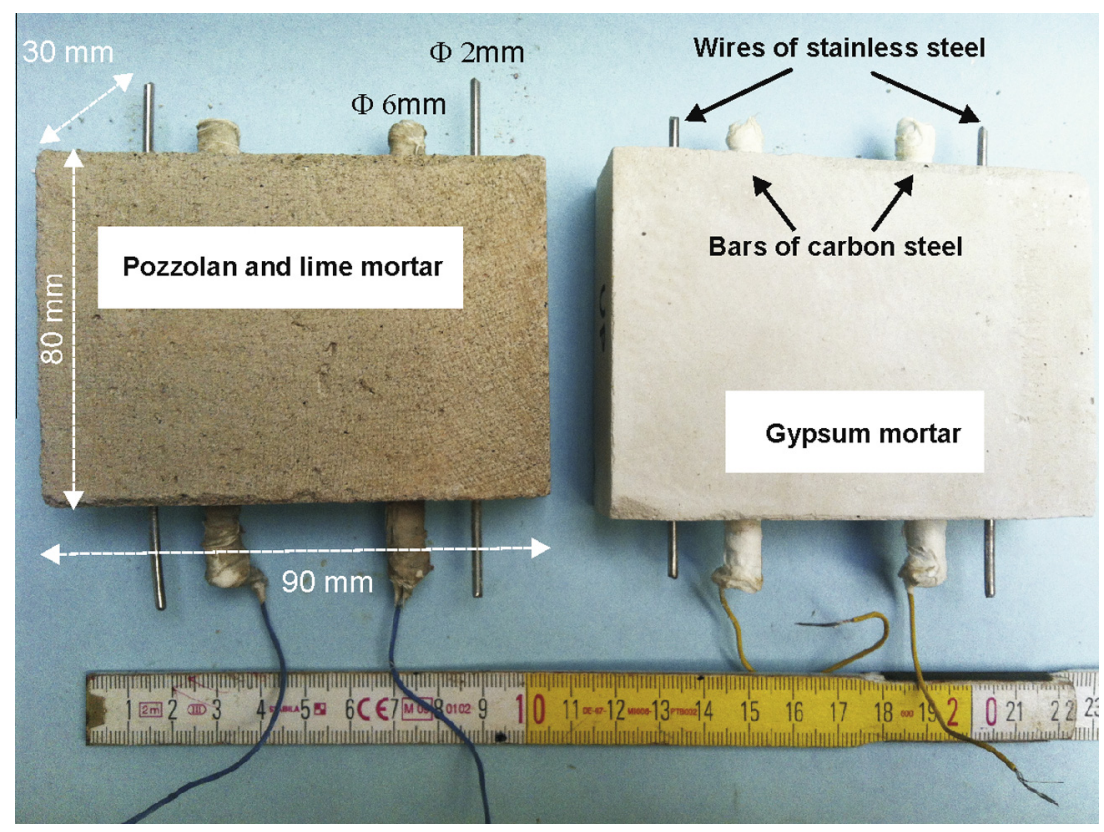

Fig. 3. Examples of reinforced specimens made with lime-pozzolana mortar (left) and gypsum mortar (right).

values for $E_{\text {corr }}$ and $i_{\text {corr. }}$. A change of the corrosion potential towards more negative values can be observed as the relative humidity increased: at $80 \% \mathrm{RH}$ and $95 \% \mathrm{RH}$ steady values respectively of $-350 \mathrm{mV}$ and $-420 \mathrm{mV}$ vs $\mathrm{Ag} / \mathrm{AgCl}$ were reached. Corrosion rate stabilized around $0.8 \mathrm{~mA} / \mathrm{m}^{2}$ at $80 \% \mathrm{RH}$ and $1-2 \mathrm{~mA} / \mathrm{m}^{2}$ at $95 \% \mathrm{RH}$ The electrical resistivity reached lower steady values following the increase in the relative humidity: it drops to steady values around $3000 \Omega \mathrm{m}$ and $1000 \Omega \mathrm{m}$ respectively at $80 \%$ and $95 \% \mathrm{RH}$.

Tests similar to those presented in Fig. 4 were carried out on the other specimens, in order to obtain results covering all the combinations of $\mathrm{RH}$ and temperature for carbon steel and selected combinations for stainless steel and titanium. Each condition of temperature and relative humidity was maintained for a time sufficient to reach stable values for $E_{\text {corr }}, i_{\text {corr }}$ and $\rho$. Normally, steady state occurred within several weeks after the relative humidity was changed and within several days when only temperature was modified, although for some specific cases shorter or longer times were required. Only the steady values of $E_{\text {corr }}, i_{\text {corr }}$ and $\rho$ will be considered in this paper.

In addition to the exposure to constant values of relative humidity in the atmosphere $(65 \%, 80 \%$ and $95 \% \mathrm{RH})$, at the last stage of the investigations all reinforced specimens were also partially immersed in water (after long-term exposure to the dry atmosphere of the lab). Specimens were placed vertically and one side parallel to the bars was immersed in water for $10 \mathrm{~mm}$ to allow water uptake towards the two steel bars placed respectively at height of 80 (A) $\mathrm{mm}$ and $20 \mathrm{~mm}$ (B) from the water level. $E_{\text {corr }}, i_{\text {corr }}$ and $\rho$ were monitored for $24 \mathrm{~h}$ and the final values achieved will be discussed in this work.

\section{Results and discussion}

Table 2 shows, for each type of mortar (G,LG, LP, LCP and $L C)$ and metal insert ( $C s=$ carbon steel, $S s=$ stainless steel and $T i=$ titanium), the average values of the steady state measurements of electrical resistivity, corrosion potential and corrosion rate obtained in different hygrothermal conditions (65\%, 80\%, 95\% $\mathrm{RH}$ and $5,20,40^{\circ} \mathrm{C}$ ). Similarly, Tables 3 and 4 show the results obtained during water uptake tests, respectively for carbon steel and stainless steel bars, respectively.

Corrosion rate and corrosion potential have been evaluated for each condition presented by average value of measurements on two replicate bars. As observed in the example of Fig. 4, the variability between replicate bars and within measurements on the same bars was, in general, modest and thus this is not reported in Tables 2 and 3. More details on the variability of the measured parameters can be found in Ref. [8].

These results will be discussed considering first the effect of environmental conditions and the type of binder on the corrosion behaviour of carbon steel. Then the behaviour of corrosion resistant materials will be analysed. Finally, electrochemical monitoring of corrosion will be addressed.

\subsection{Effect of relative humidity and temperature}

For ancient masonry the long-term exposure to the atmosphere leads to carbonation even if the mortars are made with alkaline binders (such as the mortars with addition of lime, see also Section 3.2). For this reason corrosion tests were carried out after full carbonation of the specimens. In this condition carbon steel is electrochemically active (i.e. carbonation leads to depassivation) and the corrosion rate will depend on the availability of water and oxygen in the pores of the mortar near the steel surface, hence it will be a function of environmental conditions [1,2].

Fig. 5 shows, as an example the relationship that was found between the steady-state corrosion rate of carbon steel embedded in different types of mortars and the relative humidity at a temperature of $20^{\circ} \mathrm{C}$; values measured during water uptake tests $(W U)$ are also shown on the right side of the graph. This figure clearly shows a predominant effect of moisture content with respect to the effect of the composition of the mortar. When the RH increased from $65 \%$ to $95 \%$ the corrosion rate of the steel bars increased from values of $0.01-0.1 \mathrm{~mA} / \mathrm{m}^{2}$ (about $0.01-0.1 \mu \mathrm{m} /$ year) to $1-3 \mathrm{~mA} / \mathrm{m}^{2}$ (about 1-3 $\mu \mathrm{m} /$ year), whilst differences between bars in different types of mortar were modest.

Interestingly, the corrosion rate was negligible until $80 \% \mathrm{RH}$, showing values below the threshold conventionally fixed at $1 \mathrm{~mA} / \mathrm{m}^{2}$ for steel embedded in concrete [1]). In a wet atmosphere with $95 \% \mathrm{RH}$ the corrosion rate exceeded the threshold of $1 \mathrm{~mA} / \mathrm{m}^{2}$, but the level was still modest, showing values of only few $\mathrm{mA} / \mathrm{m}^{2}$. Conversely, exposure with direct contact between the specimens and liquid water, simulated by water uptake tests, resulted into a corrosion rate value of 1-2 order of magnitude higher (values exceeding $100 \mathrm{~mA} / \mathrm{m}^{2}$ were measured on the lower bars of specimens with $G$ and $L G$ mortars).

Similar trends of corrosion rate as a function of relative humidity were confirmed by tests performed at a temperature of $5{ }^{\circ} \mathrm{C}$ and $40{ }^{\circ} \mathrm{C}$ (Table 2). Indeed, also the temperature influences the corrosion rate, as shown for instance in Fig. 6 in which the corrosion rate 

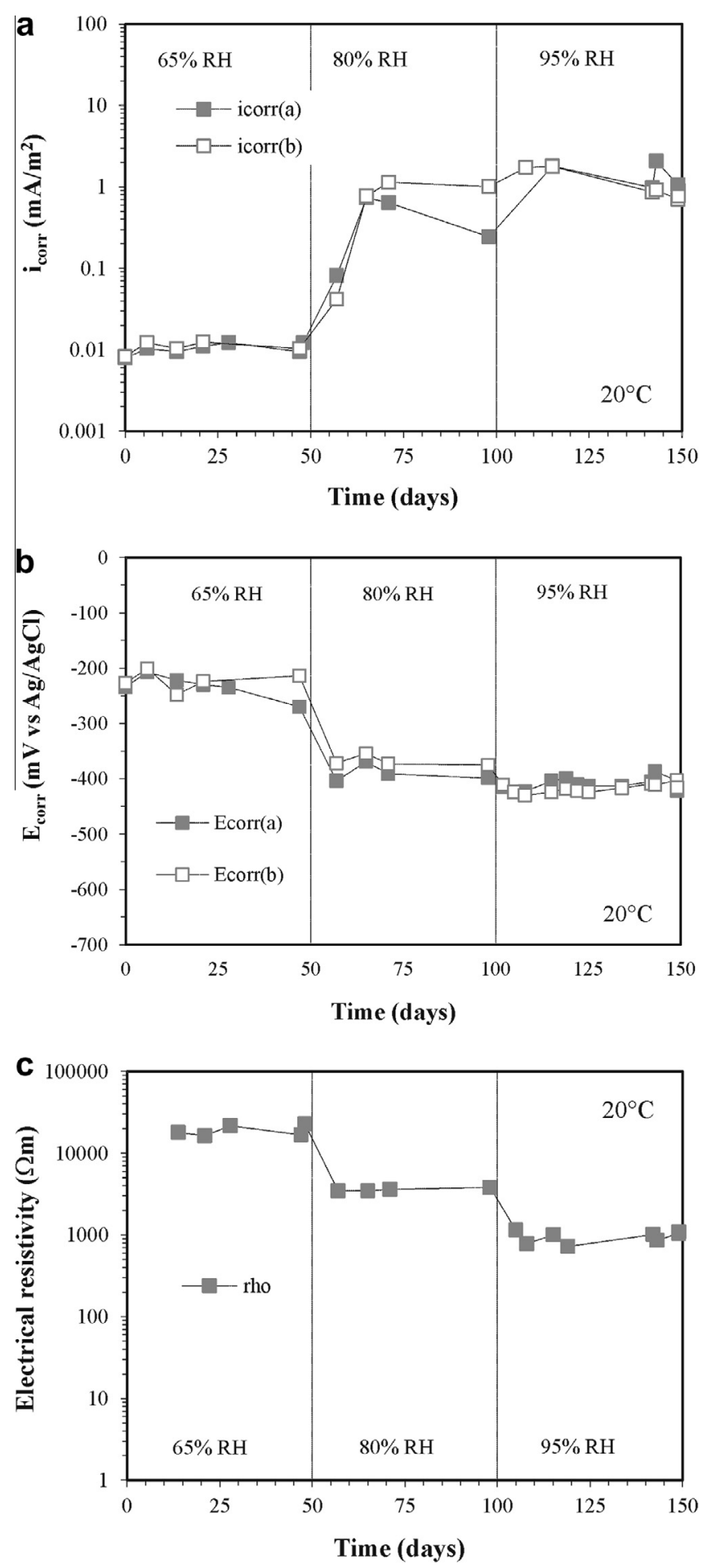

Fig. 4. Corrosion rate $i_{\text {corr }}$ (a) and corrosion potential $E_{\text {corr }}$ (b) of two carbon steel bars embedded in a $L G$ mortar specimen and mortar resistivity (c) as a function of time, in three moisture conditions $(65 \%, 80 \%$ and $95 \% \mathrm{RH})$ at $20^{\circ} \mathrm{C}$.

of carbon steel embedded in different mortars exposed at 95\% RH is plotted as a function of temperature. It can be observed that changes induced by the temperature are much lower than those induced by moisture content: by raising the temperature from $5{ }^{\circ} \mathrm{C}$ to $40{ }^{\circ} \mathrm{C}$, for $95 \% \mathrm{RH}$ the corrosion rate increases about one order of magnitude, i.e. it about doubled every $10^{\circ} \mathrm{C}$ rise in temperature (a lower effect of temperature was observed in other humidity conditions).

\subsection{Effect of binder}

Even though the moisture content seems to have a dominant influence on the corrosion rate of carbon steel embedded in mortar materials, investigating the effect of the type of mortar is nevertheless of interest, considering the great variability of materials that can be found in ancient masonry and the heterogeneous nature of these materials [7,19-22]. Especially, the type of binder may influence: the microstructure, the chemical composition of the hydration products and the pore solution in the mortar. This, in turn, may affect the corrosion behaviour of embedded steel.

When the binder is alkaline, this may induce an alkaline character to the pore solution and promote passivation of steel at early ages in the life of a building. In solutions with $\mathrm{pH}>11.5$, a very thin oxide film forms on the surface of carbon steel, reducing the corrosion rate to negligible values. The $\mathrm{pH}$ of the pore solution depends on the type of binder but it may change in time due to the carbonation reaction with carbon dioxide in the environment [2]. In order to assess the potential protective capacity of the studied mortars, $\mathrm{pH}$ measurements were carried out before and after carbonation. Fig. 7 shows that mortars with lime such as those made with lime-cocciopesto and lime-gypsum blends produce an alkaline environment the $\mathrm{pH}$ values equal to 11.8 and 12.2 , respectively, as measured with the technique used in this work (Section 2). Thus these mortars may passivate carbon steel reinforcement (at least initially). Conversely, the $\mathrm{pH}$ of gypsum mortar is near to neutrality.

Alkalinity of lime mortars was progressively neutralized by atmospheric carbon dioxide moving inward from the external surface, leading to a pH decrease. Phenolphthalein tests, carried out in order to assess the carbonation depth on a freshly fractured surface of the specimens, revealed a non-uniform carbonation front (even in the internal carbonated zone). Although most of the fractured surface was carbonated, the presence of the so called Liesegang Patterns [24], i.e. traces of still alkaline material in form of pink coloured strips in the fractured surface, was detected with the phenolphthalein test [8]. Indeed, from $\mathrm{pH}$ measurements on the powder collected from the specimens, it was observed that the $\mathrm{pH}$ of the pore solution had values of 9.9 and 11.6 respectively for $L C P$ and $L G$ samples, respectively, showing the presence of residues of non-carbonated calcium hydroxide.

As discussed in Section 3.1, once the carbon steel has become active in non-alkaline mortars, the moisture content is a key parameter in determining the corrosion rate of steel. If conditions of complete and permanent saturation of mortar are excluded, a sufficient amount of oxygen to permit the corrosion process can usually reach the surface of the steel. In this case the corrosion rate is governed by the resistivity of mortar (i.e. the corrosion process is under ohmic control, as described in Section 1) which in turn depends on moisture content and temperature. Fig. 8 shows the electrical resistivity at $20^{\circ} \mathrm{C}$ of the studied mortars as a function of different conditions of humidity. The electrical resistivity decreases as the moisture content increases. In the presence of a high water content (i.e. during water uptake tests) mortars are characterised by low electrical resistivity $(100 \Omega \mathrm{m})$, whilst in dry environments the electrical resistivity increases by many orders of magnitude.

Nevertheless, it can be also observed that the composition of the mortar has a significant influence on the electrical resistivity. At any humidity condition, higher values of electrical resistivity were measured in the hydraulic mortars ( $L C P$ and $L P$ ) than in those based on gypsum ( $G$ and $L G$ ). These differences may be attributed to both the microstructure of the mortar and the chemical composition of the pore solution. Considering that gypsum-based mortars had higher compressive strength which suggests a lower porosity and thus a higher resistivity for given moisture conditions would be expected, these differences can be attributed mainly to 
Table 2

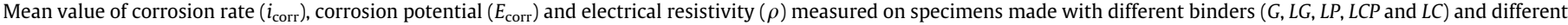
metallic inserts $(C S=$ carbon steel, $S s=$ stainless steel and $T i=$ titanium), exposed in different test conditions.

\begin{tabular}{|c|c|c|c|c|c|c|c|c|c|}
\hline \multirow[t]{2}{*}{ Binder } & \multirow[t]{2}{*}{$\begin{array}{l}\text { Relative humidity } \\
(\%)\end{array}$} & \multirow[t]{2}{*}{$\begin{array}{l}\text { Temperature } \\
\left({ }^{\circ} \mathrm{C}\right)\end{array}$} & \multicolumn{3}{|c|}{$\begin{array}{l}i_{\text {corr }} \\
\left(\mathrm{mA} / \mathrm{m}^{2}\right)\end{array}$} & \multicolumn{3}{|c|}{$\begin{array}{l}E_{\text {corr }} \\
(\mathrm{mV} \text { vs } \mathrm{Ag} / \mathrm{AgCl})\end{array}$} & \multirow[t]{2}{*}{$\begin{array}{l}\rho \\
(\Omega \mathrm{m})\end{array}$} \\
\hline & & & Cs & Ss & $\mathrm{Ti}$ & Cs & Ss & $\mathrm{Ti}$ & \\
\hline \multirow[t]{9}{*}{$G$} & \multirow[t]{3}{*}{65} & 5 & 0.04 & - & - & -138 & - & - & $9.9 \cdot 10^{2}$ \\
\hline & & 20 & 0.07 & 0.08 & - & -227 & -69 & - & $2.3 \cdot 10^{3}$ \\
\hline & & 40 & 0.05 & 0.01 & - & -165 & +32 & - & $1.8 \cdot 10^{4}$ \\
\hline & \multirow[t]{3}{*}{80} & 5 & 0.48 & - & - & -234 & - & - & $6.1 \cdot 10^{2}$ \\
\hline & & 20 & 0.91 & 0.09 & - & -329 & +65 & - & $5.3 \cdot 10^{2}$ \\
\hline & & 40 & 1.12 & 0.09 & - & -357 & +30 & - & $3.7 \cdot 10^{2}$ \\
\hline & \multirow[t]{3}{*}{95} & 5 & 2.63 & - & - & -314 & - & - & $2.7 \cdot 10^{2}$ \\
\hline & & 20 & 3.34 & 0.08 & 0.02 & -382 & +85 & 139 & $2.2 \cdot 10^{2}$ \\
\hline & & 40 & 29.6 & 0.05 & - & -391 & +100 & - & $3.7 \cdot 10$ \\
\hline \multirow[t]{9}{*}{$L G$} & \multirow[t]{3}{*}{65} & 5 & 0.01 & - & - & -200 & - & - & $1,4 \cdot 10^{4}$ \\
\hline & & 20 & 0.01 & 0.05 & - & -228 & +10 & - & $1.9 \cdot 10^{4}$ \\
\hline & & 40 & 0.01 & 0.01 & - & -219 & +18 & - & $1,8 \cdot 10^{5}$ \\
\hline & \multirow[t]{3}{*}{80} & 5 & 0.31 & - & - & -269 & - & - & $1.4 \cdot 10^{3}$ \\
\hline & & 20 & 0.70 & 0.12 & - & -369 & +78 & - & $2.2 \cdot 10^{3}$ \\
\hline & & 40 & 0.21 & 0.07 & - & -413 & +15 & - & $6.7 \cdot 10^{3}$ \\
\hline & \multirow[t]{3}{*}{95} & 5 & 0.91 & - & - & -299 & - & - & $9.1 \cdot 10^{2}$ \\
\hline & & 20 & 1.33 & 0.09 & 0,04 & -415 & +106 & 37 & $1.5 \cdot 10^{3}$ \\
\hline & & 40 & 11.2 & 0.06 & - & -449 & +123 & - & $1.1 \cdot 10^{2}$ \\
\hline \multirow[t]{9}{*}{$L P$} & \multirow[t]{3}{*}{65} & 5 & 0.01 & - & - & -142 & - & - & $2.5 \cdot 10^{4}$ \\
\hline & & 20 & 0.02 & 0.02 & - & -175 & +34 & - & $6.7 \cdot 10^{4}$ \\
\hline & & 40 & 0.09 & 0.02 & - & -217 & +150 & - & $3.0 \cdot 10^{6}$ \\
\hline & \multirow[t]{3}{*}{80} & 5 & 0.16 & - & - & -235 & - & - & $4.8 \cdot 10^{3}$ \\
\hline & & 20 & 0.52 & 0.05 & - & -321 & +64 & - & $2.3 \cdot 10^{4}$ \\
\hline & & 40 & 1.01 & 0.05 & - & -385 & +11 & - & $1.9 \cdot 10^{4}$ \\
\hline & \multirow[t]{3}{*}{95} & 5 & 0.91 & - & - & -285 & - & - & $1.2 \cdot 10^{3}$ \\
\hline & & 20 & 3.75 & 0.04 & 0,01 & -420 & +52 & -122 & $8.0 \cdot 10^{3}$ \\
\hline & & 40 & 4.47 & 0.07 & - & -432 & +72 & - & $2.7 \cdot 10^{2}$ \\
\hline \multirow[t]{9}{*}{$L C P$} & \multirow[t]{3}{*}{65} & 5 & 0.03 & - & - & -209 & - & - & $6.0 \cdot 10^{4}$ \\
\hline & & 20 & 0.01 & 0.01 & - & -213 & +50 & - & $2.7 \cdot 10^{5}$ \\
\hline & & 40 & 0.01 & 0.01 & - & -151 & +144 & - & $3.1 \cdot 10^{6}$ \\
\hline & \multirow[t]{3}{*}{80} & 5 & 0.22 & - & - & -240 & - & - & $1.0 \cdot 10^{4}$ \\
\hline & & 20 & 0.45 & 0.05 & - & -333 & +98 & - & $4.5 \cdot 10^{4}$ \\
\hline & & 40 & 0.53 & 0.06 & - & -395 & -38 & - & $1.9 \cdot 10^{4}$ \\
\hline & \multirow[t]{3}{*}{95} & 5 & 0.82 & - & - & -319 & - & - & $3.0 \cdot 10^{3}$ \\
\hline & & 20 & 3.25 & 0.05 & 0.02 & -406 & +36 & 99 & $1.3 \cdot 10^{3}$ \\
\hline & & 40 & 11.9 & 0.08 & - & -432 & +104 & - & $5.6 \cdot 10^{2}$ \\
\hline$L C$ & 95 & 20 & 14.1 & 0.06 & - & -469 & +25 & - & \\
\hline
\end{tabular}

differences in the composition of the pore solution. Gypsum-based mortars contain in their pore sulphate ions in their pores which favour ionic movement and thus reduce the electrical resistivity compared to carbonated hydraulic mortars in which the pore solution is expected to have a negligible ionic content [25]. By comparing Fig. 8 with Fig. 5, however, it can be observed that the different resistivity of the mortars is not directly correlated to the corrosion rate of embedded steel; in fact, differences in corrosion rate of steel between different mortars at the same moisture content are smaller than differences in resistivity.

A relationship similar to that of Fig. 8 was also found for all mortars studied, exposed at a temperature of $40{ }^{\circ} \mathrm{C}$ (Fig. 9). At higher temperature, however, even higher resistivity values were measured on the mortars exposed to the dry environment.

\subsection{Corrosion resistant metal inserts}

Reinforcing bars with a higher corrosion resistance than the common carbon steel rebars can be used in restoration works to replace corrosion-damaged ancient steel inserts. Although stainless steel and titanium are not expected to corrode in carbonated mortars (even when exposed to an aggressive environment), their use as reinforcement in ancient masonry is poorly documented [26-28]. Hence, AISI 304 stainless steel and titanium bars were used in order to study their corrosion behaviour in various mortars.
Fig. 10 compares the corrosion rate of different metal inserts (carbon steel, stainless steel and titanium are indicated in black, red and green, respectively). In all mortars stainless steel inserts embedded showed negligible corrosion rates (below $0.1 \mathrm{~mA} / \mathrm{m}^{2}$ ), even in the presence of water uptake. Negligible corrosion rates were measured also at a temperature of $40^{\circ} \mathrm{C}$ (Table 2).

Titanium was tested in contact with the studied mortars exposed to $95 \% \mathrm{RH}$ and a negligible corrosion rate (not exceeding $0.02-0.04 \mathrm{~mA} / \mathrm{m}^{2}$ ) was observed, even in gypsum mortars (Fig. 10). These results confirm that, when ancient inserts may be replaced or new reinforcement needs to be added to the masonry, even the use of common 304L stainless steel (with about $18 \% \mathrm{Cr}$ and $8 \% \mathrm{Ni}$ ) may be a durable solution (at least in mortars not contaminated by chlorides).

\subsection{Corrosion monitoring}

The dominant role of the moisture conditions in the corrosion behaviour discussed in Sections 3.1 and 3.2 suggests that the control of humidity may be a practical means for the preservation of steel inserts embedded in mortars. Any intervention aimed at reducing the moisture content in the masonry (e.g. controlling environmental humidity, preventing water ingress or favouring evaporation) may be effective in reducing the corrosion rate to negligible values. Such a conservation strategy, however, requires 
Table 3

Mean value of corrosion rate $\left(i_{\text {corr }}\right)$, corrosion potential $\left(E_{\text {corr }}\right)$ and electrical resistivity $(\rho)$ measured on specimens, made with different binders $(G, L G, L P, L C P$ and $L C)$ and carbon steel bars, partially immersed (values relative to the bars placed at height of $20 \mathrm{~mm}$ (B) and $80 \mathrm{~mm}$ (A) from water level) and exposed to different temperatures.

\begin{tabular}{|c|c|c|c|c|c|}
\hline Binder & $\begin{array}{l}\text { Water uptake } \\
\text { (bar position) }\end{array}$ & $\begin{array}{l}\text { Temperature } \\
\left({ }^{\circ} \mathrm{C}\right)\end{array}$ & $\begin{array}{l}i_{\text {corr }} \\
\left(\mathrm{mA} / \mathrm{m}^{2}\right)\end{array}$ & $\begin{array}{l}E_{\text {corr }} \\
(\mathrm{mV} \text { vs } \mathrm{Ag} / \mathrm{AgCl})\end{array}$ & $\begin{array}{l}\rho \\
(\Omega \mathrm{m})\end{array}$ \\
\hline \multirow[t]{6}{*}{$G$} & $A$ & \multirow[t]{2}{*}{5} & 48.7 & -392 & \multirow[t]{2}{*}{$1.2 \cdot 10^{2}$} \\
\hline & $B$ & & 70.3 & -396 & \\
\hline & $A$ & \multirow[t]{2}{*}{20} & 53.3 & -429 & \multirow[t]{2}{*}{8.0} \\
\hline & $B$ & & 86.8 & -471 & \\
\hline & A & \multirow[t]{2}{*}{40} & 67.9 & -438 & \multirow[t]{2}{*}{6.0} \\
\hline & $B$ & & 114.2 & -469 & \\
\hline \multirow[t]{6}{*}{$L G$} & $A$ & \multirow[t]{2}{*}{5} & 66.1 & -388 & \multirow[t]{2}{*}{$1.1 \cdot 10$} \\
\hline & $B$ & & 93.9 & -424 & \\
\hline & A & \multirow[t]{2}{*}{20} & 64.9 & -499 & \multirow[t]{2}{*}{9.0} \\
\hline & $B$ & & 104.3 & -528 & \\
\hline & $A$ & \multirow[t]{2}{*}{40} & 108.0 & -475 & \multirow[t]{2}{*}{5.0} \\
\hline & $B$ & & 189.3 & -477 & \\
\hline \multirow[t]{6}{*}{$L P$} & $A$ & \multirow[t]{2}{*}{5} & 14.7 & -367 & \multirow[t]{2}{*}{$2.6 \cdot 10^{2}$} \\
\hline & $B$ & & 14.5 & -339 & \\
\hline & $A$ & \multirow[t]{2}{*}{20} & 28.1 & -571 & \multirow[t]{2}{*}{$9.9 \cdot 10$} \\
\hline & $B$ & & 29.5 & -521 & \\
\hline & $A$ & \multirow[t]{2}{*}{40} & 38.6 & -447 & \multirow[t]{2}{*}{$7.5 \cdot 10$} \\
\hline & $B$ & & 38.8 & -480 & \\
\hline \multirow[t]{6}{*}{$L C P$} & A & \multirow[t]{2}{*}{5} & 22.6 & -341 & \multirow[t]{2}{*}{$2.8 \cdot 10^{2}$} \\
\hline & $B$ & & 18.5 & -306 & \\
\hline & $A$ & \multirow[t]{2}{*}{20} & 45.5 & -577 & \multirow[t]{2}{*}{$8.0 \cdot 10$} \\
\hline & $B$ & & 43.7 & -558 & \\
\hline & $A$ & \multirow[t]{2}{*}{40} & 53.9 & -458 & \multirow[t]{2}{*}{$6.3 \cdot 10$} \\
\hline & $B$ & & 51.7 & -472 & \\
\hline \multirow[t]{6}{*}{$L C$} & A & \multirow[t]{2}{*}{5} & 10.5 & -387 & \multirow[t]{2}{*}{$7.9 \cdot 10$} \\
\hline & $B$ & & 22.8 & -383 & \\
\hline & A & 20 & 42.0 & -551 & $3.4 \cdot 10$ \\
\hline & $B$ & & 40.4 & -546 & \\
\hline & $A$ & 40 & 38.6 & -447 & $7.5 \cdot 10$ \\
\hline & $B$ & & 38.8 & -480 & \\
\hline
\end{tabular}

the monitoring of the moisture content of the mortar. Unfortunately, the on-site measurement of corrosion rate of embedded metals is rather difficult. Other types of measurements, such as the corrosion potential of the metal and the electrical resistivity of the mortar can be carried out easily, even with embedded probes that allow continuous monitoring, similar to those normally used to monitor corrosion of steel reinforcement in concrete structures $[29,30]$.

The results summarised in Table 2 show that the measurement of the corrosion potential is a useful non-destructive means to assess corrosion behaviour of steel even in mortars of different composition. In fact, the corrosion potential is influenced by the exposure condition, as shown for instance in Fig. 11. In moist mortars (e.g. at $95 \% \mathrm{RH}$ or during water uptake) at $20^{\circ} \mathrm{C}$ the corrosion potential of carbon steel in carbonated mortars dropped below $-400 \mathrm{mV}$ vs $\mathrm{Ag} / \mathrm{AgCl}$ whilst in dry conditions (65-80\% $\mathrm{RH}$ ) it was around $-200 \mathrm{mV}$ vs $\mathrm{Ag} / \mathrm{AgCl}$. Even more negative values of corrosion potential were reached at $40{ }^{\circ} \mathrm{C}$ (when compared to those achieved at 5 and $20^{\circ} \mathrm{C}$, Table 2) already for relative humidity of

Table 4

Mean value of corrosion rate $\left(i_{\text {corr }}\right)$, corrosion potential $\left(E_{\text {corr }}\right)$ and electrical resistivity $(\rho)$ measured on specimens, made with different binders ( $L G, L P, L C P$ and $L C)$ and stainless steel bars, exposed to $20^{\circ} \mathrm{C}$ (values relative to the bar placed at a height of $20 \mathrm{~mm}$ from water level (position b)).

\begin{tabular}{llll}
\hline Binder & $\begin{array}{l}i_{\text {corr }} \\
\left(\mathrm{mA} / \mathrm{m}^{2}\right)\end{array}$ & $\begin{array}{l}E_{\text {corr }} \\
(\mathrm{mV} \text { vs } \mathrm{Ag} / \mathrm{AgCl})\end{array}$ & $\begin{array}{l}\rho \\
(\Omega \mathrm{m})\end{array}$ \\
\hline$L G$ & 0.10 & +44 & 9.0 \\
$L P$ & 0.07 & +34 & $9.9 \cdot 10$ \\
$L C P$ & 0.06 & +38 & $8.0 \cdot 10$ \\
$L C$ & 0.07 & +19 & $3.4 \cdot 10$ \\
\hline
\end{tabular}

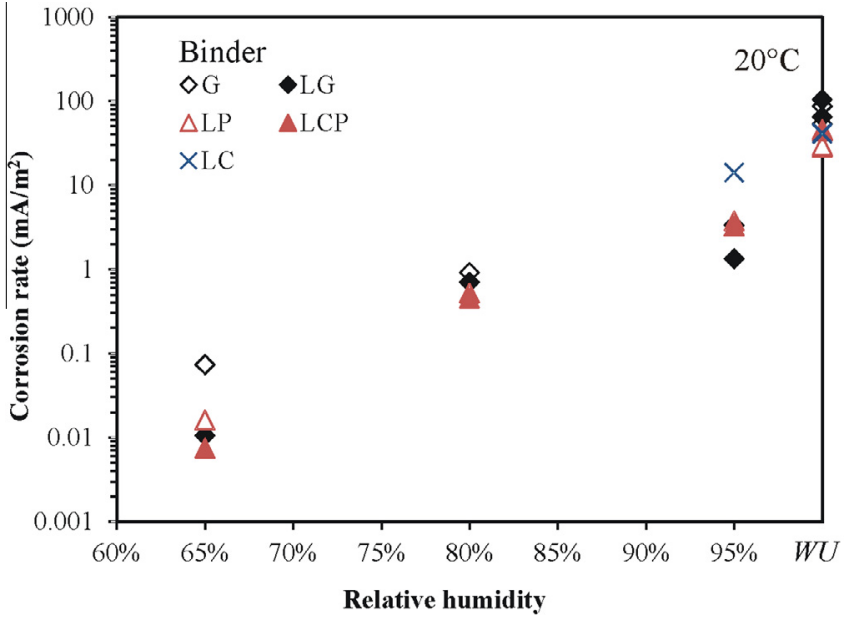

Fig. 5. Average corrosion rate of carbon steel embedded in $G, L G, L P, L C P$ and $L C$ mortars as a function of relative humidity at $20^{\circ} \mathrm{C}$

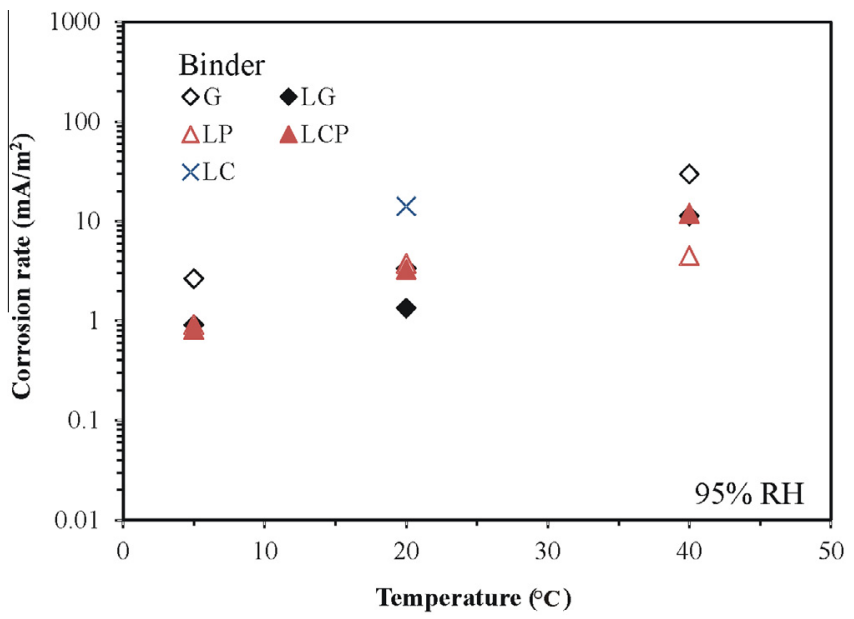

Fig. 6. Average corrosion rate of carbon steel embedded in $G, L G, L P, L C P$ and $L C$ mortars as a function of different temperatures at a relative humidity of $95 \%$.

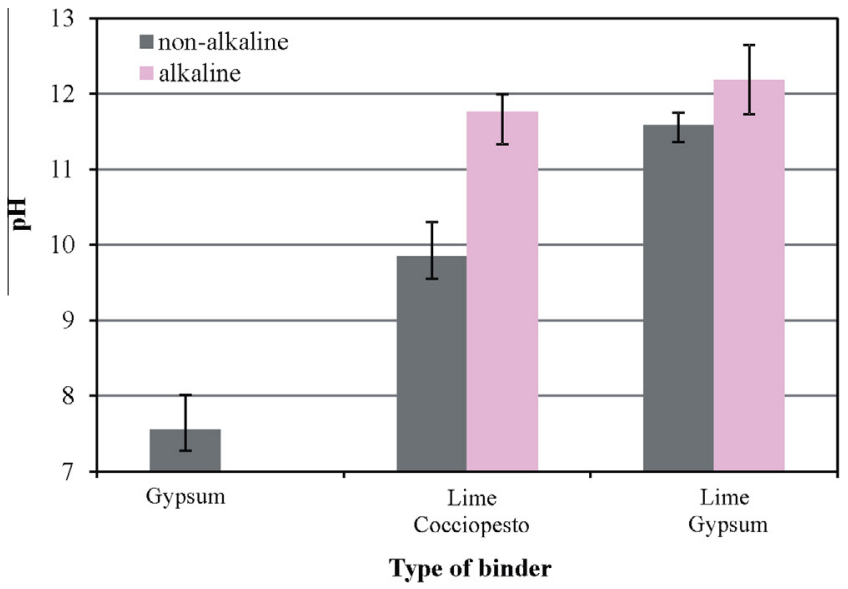

Fig. 7. pH of pore solution of mortars made with different binders in alkaline and non-alkaline conditions.

80-95\%. The type of mortar only slightly affected the measurements of corrosion potential (differences of less than $50 \mathrm{mV}$ were observed in most of the conditions). 
Fig. 12 shows the relationship between corrosion potential and corrosion rate for all types of mortar and metal inserts when exposed to different humidities at $20^{\circ} \mathrm{C}$. For stainless steel and titanium inserts experimental results lay within a passivity range (identified by $E_{\text {corr }}>-150 \mathrm{mV}$ vs $\mathrm{Ag} / \mathrm{AgCl}$ and $i_{\text {corr }}<1 \mathrm{~mA} / \mathrm{m}^{2}$ ), regardless of relative humidity and type of binders. This behaviour is consistent with the anodic control of the corrosion process due to passivity of the two metals $[1,2]$.

For carbon steel, the corrosion behaviour depends on the relative humidity and there is an inverse relationship between the corrosion potential and the corrosion rate. From Fig. 12 it can be seen that negligible corrosion rates were measured for carbon steels embedded in all types of (carbonated) mortars until they were exposed to $80 \% \mathrm{RH}$; for relative humidities above $95 \% \mathrm{RH}$ the corrosion potential decreased from $-400 \mathrm{mV}$ to $-600 \mathrm{vs} \mathrm{Ag} / \mathrm{AgCl}$ as the moisture content increased and the corrosion rate showed a roughly exponential relationship (i.e. linear in the logarithmic scale of Fig. 12) with $i_{\text {corr }}$ reaching values of the order of $100 \mathrm{~mA} / \mathrm{m}^{2}$ when $E_{\text {corr }}$ approached $-600 \mathrm{mV}$. This behaviour can be explained by an ohmic control of the corrosion process and it is consistent with the anodic-resistive control proposed by Glass et al. [31]. It should, however, be observed that the corrosion potential values

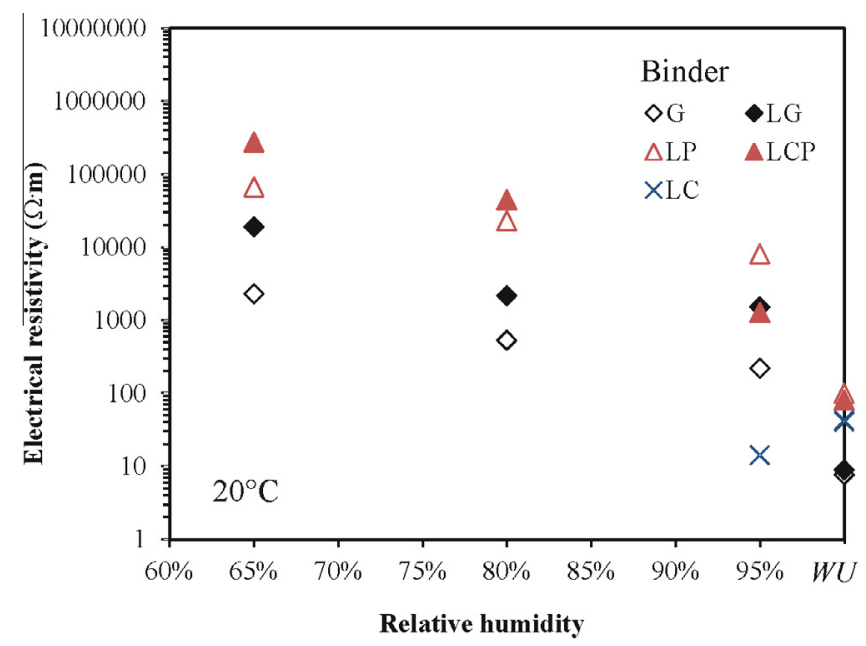

Fig. 8. Electrical resistivity as a function of relative humidity, measured at $20^{\circ} \mathrm{C}$ on reinforced specimens made with different binders.

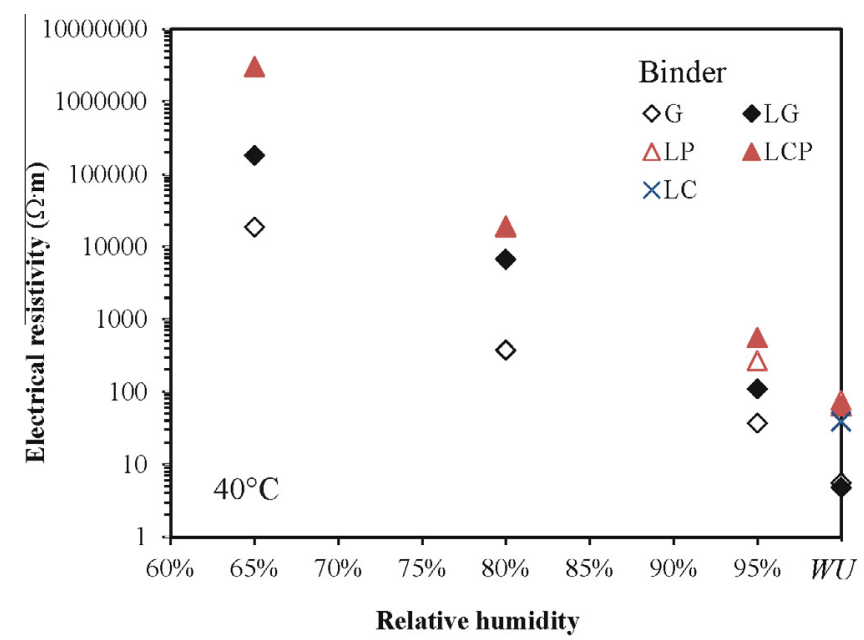

Fig. 9. Electrical resistivity as a function of relative humidity, measured at $40^{\circ} \mathrm{C}$ on reinforced specimens made with different binders. measured in this study on the steel bars in dry carbonated mortars are lower than those usually measured on steel bars embedded in carbonated concrete (were usually higher values higher than $-200 \mathrm{mV}$ vs SCE are measured [2]) and this aspect needs to be further investigated.

In case a continuous monitoring is needed, measurements of the corrosion potential require the use of embedded reference electrodes, however their stability in the course of time is questionable [32]. In real structures it is much easier to perform monitoring of the electrical resistivity by means of embedded resistivity probes.

Since the resistivity of wet and dry mortars varies by several orders of magnitude, measurements of resistivity can provide a sensitive means for detecting the risk of corrosion. Fig. 13 shows the relationship between electrical resistivity and corrosion rate of carbon steel measured at $20^{\circ} \mathrm{C}$ (in different conditions of relative humidity).

It can be seen that in conditions of high humidity (i.e. for electrical resistivity less than 100-200 $\Omega \mathrm{m}$ ), the carbon steel bars in carbonated lime-mortars or gypsum mortars show an increase of corrosion rate (reaching $100 \mathrm{~mA} / \mathrm{m}^{2}$ for gypsum-based mortars).

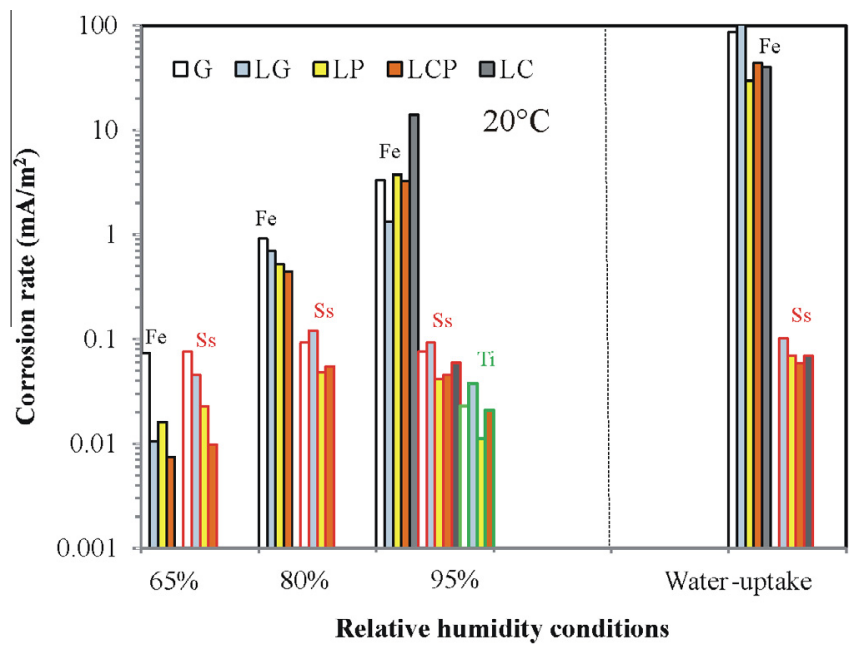

Fig. 10. Average corrosion rate measured on different types of inserts $(F e=$ carbon steel, $S s=$ stainless steel, $T i=$ titanium) made with different binders exposed at $20{ }^{\circ} \mathrm{C}$ in different moisture conditions.

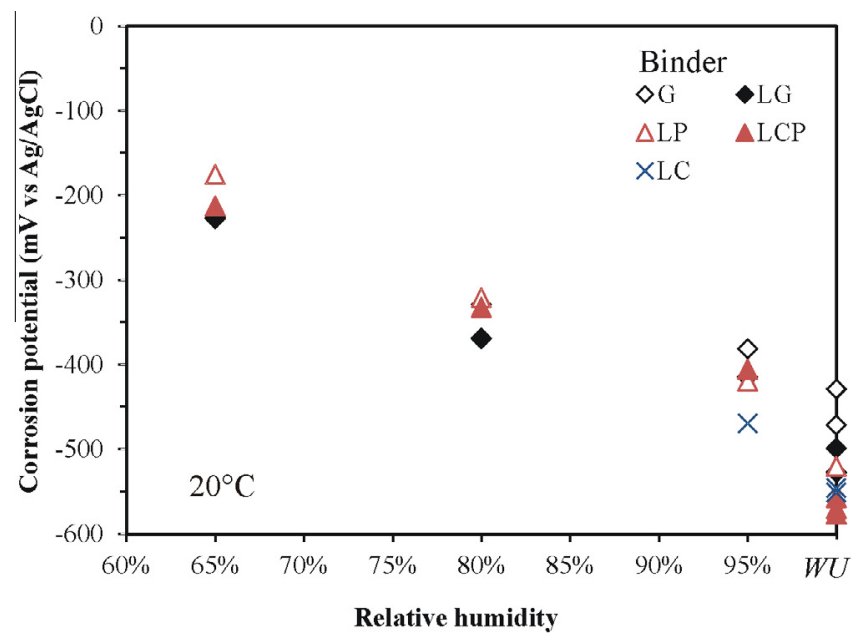

Fig. 11. Corrosion potential as a function of relative humidity measured at $20^{\circ} \mathrm{C}$ on reinforced specimens made with different binders. 


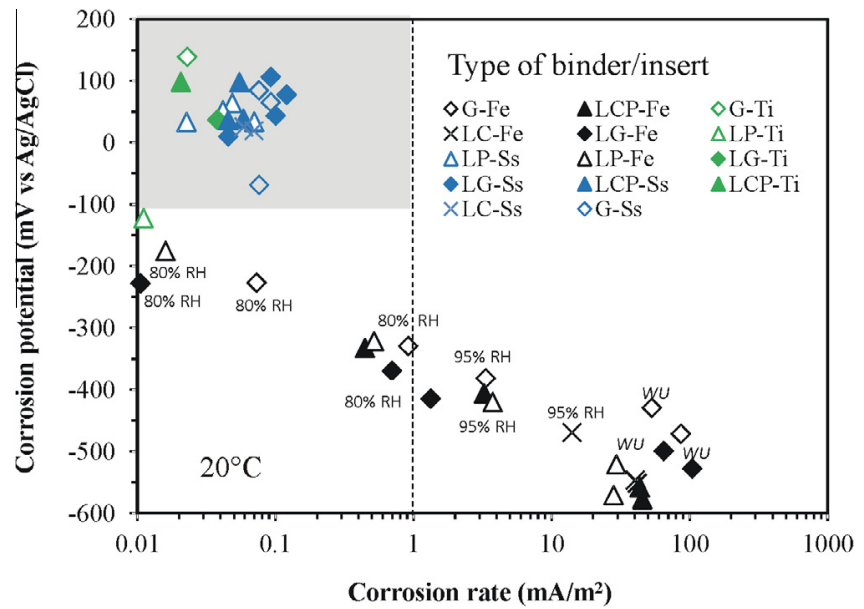

Fig. 12. Corrosion potential as a function of corrosion rate measured at $20^{\circ} \mathrm{C}$ (in different relative humidity) on reinforced specimens made with different binders.

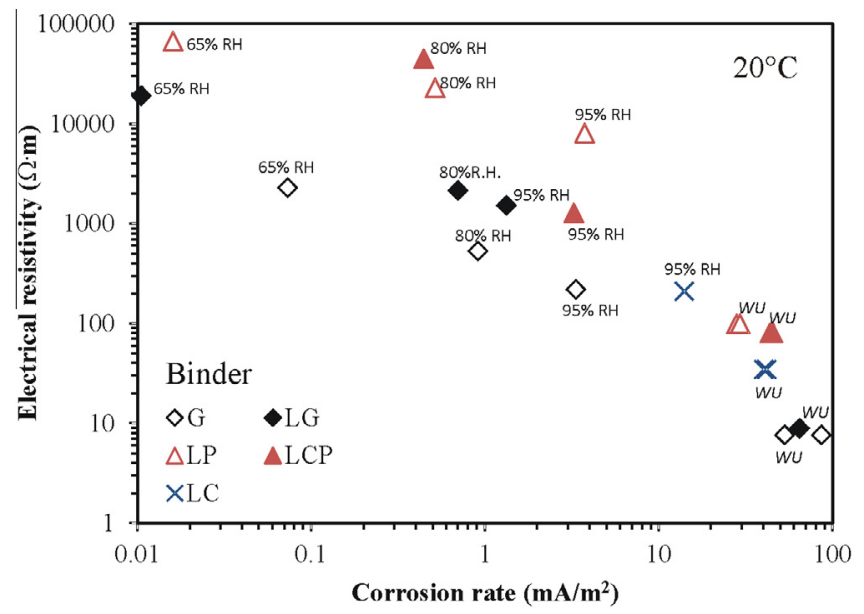

Fig. 13. Electrical resistivity as a function of corrosion rate of carbon steel bars measured at $20^{\circ} \mathrm{C}$ (in different conditions of relative humidity) on reinforced specimens made with different binders.

Similar relationships can be obtained at other temperatures considering data of Table 2 . Therefore monitoring of electrical resistivity can be a simple way to verify the corrosion conditions of embedded steel in carbonated mortars as a function of environmental exposure conditions. However, it should be noted that resistivity is significantly influenced by the composition of the pore solution of the mortar (Figs. 8 and 9) [33] and thus different correlations with $i_{\text {corr }}$ may apply depending on the type of binder (and possibly on salt contamination). Furthermore, in warm environments the resistivity technique may not be applicable when the pore solution in the pores may dry out and electrodes may be influenced by surface effects. Finally, it should be borne in mind that this relationship does not apply to passive metals (e.g. stainless steel, titanium or even carbon steel in contact with alkaline mortars).

It is worth to mention that a problem similar to that described in this work exists with steel-framed structures where the steel is encased in mortar or masonry. Corrosion of the steel forces movement of masonry, cracking and spalling [3]. Cathodic protection, which is often used for steel bars in carbonated concrete [34], has been also applied to some of these structures but this is a very expensive remediation option. Monitoring of resistivity as suggested in this work should allow earlier and much simpler interventions.

\section{Conclusions}

The results of this study showed the key role of temperature, relative humidity and water uptake in the corrosion behaviour of metal inserts embedded in mortars used in ancient masonry.

Corrosion rate of carbon steel inserts embedded in aerial and hydraulic mortars was negligible if exposed to a relative humidity of $65-80 \%$ (even at temperature of $40^{\circ} \mathrm{C}$ ). Conversely, in wet environments and especially in the presence of water suction, the corrosion rate reached high values, approaching $100 \mathrm{~mA} / \mathrm{m}^{2}$ when carbon steel was in contact with gypsum-based mortars. The type of mortar had only a slight influence on the corrosion behaviour of steel inserts. Inserts made of a common stainless steel 304L, similarly as titanium, can demonstrate a high corrosion resistance, regardless of the material in contact with inserts and exposure conditions.

It was shown that, by considering the correlations between electrical resistivity of the embedding material and corrosion rate of the insert, it is possible to evaluate indirectly the corrosion rate of carbon steel inserts by monitoring of electrical resistivity of the mortar as a function of moisture fluctuation and, possibly, of the corrosion potential of the steel.

\section{References}

[1] L.L. Shreir, R.A. Jarman, G.T. Burstein (Eds.), Corrosion, vol. 1, third ed., in: Metals/Environment Reactions, Butterworth Heinemann, Oxford, 1993.

[2] L. Bertolini, B. Elsener, P. Pedeferri, E. Redaelli, R. Polder, Corrosion of Steel in Concrete - Prevention, Diagnosis, Repair, second ed., Wiley VCH, Weinheim, 2013.

[3] P. Gibbs (Ed.), Corrosion in Masonry Clad Early 20th Century Steel Framed Buildings, Historic Scotland, Edinburgh, 2000.

[4] P.B. Lourenco, Recommendations for restoration of ancient buildings and the survival of a masonry chimney, Constr. Build. Mater. 20 (2006) 239-251.

[5] U. Nürnberger, Corrosion of metals in contact with mineral building materials, in: M. Raupach, B. Elsener, R. Polder, J. Mietz (Eds.), Corrosion of Reinforcement in Concrete. Mechanism, Monitoring, Inhibitors and Rehabilitation Techniques, European Federation of Corrosion Publication number, Woodhead Publishing Limited, Cambridge, 2001, pp. 1-9.

[6] L. Bertolini, M. Carsana, M. Gastaldi, F. Lollini, E. Redaelli, Corrosion assessment and restoration strategies of reinforced concrete buildings of the cultural heritage, Mater. Corros. 62 (2011) 146-154.

[7] L. Bertolini, M. Carsana, E. Marra, Degradation of mortars and steel inserts from the ciborium of the medieval abbey of San Pietro al Monte, Special Topics on Materials Science and Technology - An Italian Panorama, Brill Publisher, 2009.

[8] L. Bertolini, M. Carsana, B. Daniotti, E. Marra, Environmental factors affecting corrosion of steel inserts in ancient masonry, in: Proceedings of the 12th International Conference on Durability of Building Materials and Components, Porto, 12-15 April; 2011.

[9] R. Fort Gonzalez, M. Alvarez De Buergo, F. Mingarro Martìn, M.C. Lopez De Azcona, Stone decay in 18th century monuments due to iron corrosion. The Royal Palace, Madrid (Spain), Build. Environ. 39 (2004) 357-364.

[10] F.M. Schulz, G.S. Duffò, S.B. Farina, Corrosion resistant of commercial metallic materials in contact with mortar, Proc. Mater. Sci. 1 (2012) 243-250.

[11] M. Collepardi, Degradation and restoration of masonry walls of historical buildings, Mater. Struct. 23 (1990) 81-102.

[12] B.H. Vos, Suction of groundwater, Stud. Conserv. 16 (1971) 129-144.

[13] L. Bertolini, L. Coppola, M. Gastaldi, E. Redaelli, Electroosmotic transport in porous construction materials and dehumidification of masonry, Constr. Build. Mater. 23 (2009) 254-263.

[14] H. Arup, The mechanisms of the protection of steel by concrete, in: A.P. Crane (Ed.), Corrosion of Reinforcement in Concrete Construction, Hellis Horwood Ltd., Chichester, 1983, pp. 151-157.

[15] K. Tuutti, Corrosion of Steel in Concrete, Swedish Foundation for Concrete Research, Stockholm, 1982.

[16] C.L. Page, Corrosion and its control in reinforced concrete, the sixth Sir Lea F memorial lecture, in: 26th Annual convention of the Institute of Concrete Technology, Bosworth (UK), 6-8 April 1998.

[17] P.H. Dillmann, R. Balasubramanian, G. Beranger, Characterization of protective rust on ancient Indian iron using microprobe analyses, Corros. Sci. 44 (2002) $2231-2242$.

[18] J.J. Santana Rodriguez, F.J. Santana Hernàndez, J.E. Gonzalez, XRD and SEM studies of the layer of corrosion products for carbon steel in various different 
environments in the province of Las Palmas (The Canary Islands, Spain), Corros. Sci. 44 (2002) 2425-2438.

[19] C. Sabbioni, A. Bonazza, G. Zappia, Damage on hydraulic mortars: the Venice Arsenal, J. Cult. Herit. 3 (2002) 83-88.

[20] C. Genestar, C. Pons, A. Màs, Analytical characterisation of ancient mortars from the archeological Roman city of Pollentia (Balearic Island, Spain), Anal. Chim. Acta 557 (2006) 373-379.

[21] M. Lezzerini, S. Legnaioli, G. Lorenzetti, V. Palleschi, M. Tamponi, Characterization of historical mortars from the bell tower of St. Nicholas church (Pisa, Italy), Constr. Build. Mater. 69 (2014) 203-212.

[22] L. Bertolini, M. Carsana, M. Gastaldi, F. Lollini, E. Redaelli, Binder characterisation of mortars used at different ages in the San Lorenzo church in Milan, Mater. Charact. 80 (2013) 9-20.

[23] M. Carsana, M. Frassoni, L. Bertolini, Comparison of ground waste glass with other supplementary cementitious materials, Cem. Concr. Compos. 45 (2014) $39-45$.

[24] C. Rodriguez-Navarro, O. Cazalla, K. Elert, E. Sebastian, Liesegang pattern development in carbonating traditional lime mortars, R. Soc. 458 (2002) 22612273.

[25] G. Sergi, Corrosion of steel in concrete: cement matrix variables (Ph.D. thesis), University of Aston, Birmingham, 1986.

[26] Assimina V. Dremetsika, Panayotis A. Siskos, Evangelos B. Bakeas, The Acropolis case and the Parthenon marbles, in: 8th FECS Conference 2002.
27] F.M. Mazzolani, A. Mandara, Modern trends in the use of special metals for the improvement of historical and monumental structures, Eng. Struct. 24 (2002) $843-856$.

[28] Ministry of Culture and Committee for the preservation of the Acropolis Monuments, A Study for Restoration of the Parthenon, Athens, vol. II, 1989.

[29] D. Bürchler, B. Elsener, H. Böhni, Electrical resistivity and dielectric properties of hardened cement paste and mortar, in: Gerhardt RA, Taylor SR, Garborczi E] (Eds.), Electrically Based Micro Structural Characterization, Mat. Res. Soc. Symp. Proc., vol. 411, 1996, pp. 407.

[30] L. Bertolini, R.B. Polder, Concrete resistivity and reinforced corrosion rate as a function of temperature and humidity of the environment, TNO-Report, 97BT-R0574, 1997.

[31] G.K. Glass, C.L. Page, N.R. Short, Factors affecting the corrosion rate of steel in carbonated mortars, Corros. Sci. 32 (1991) 1283-1294.

[32] R. Myrdal, The electrochemistry and characteristics of embeddable reference electrodes for concrete, Woodhead Publishing Limited, Cambridge, 2007 (European Federation of Corrosion Publication number 43).

[33] C. Alonso, C. Andrade, J.A. Gonzales, Relation between resistivity and corrosion rate of reinforcements in carbonated mortar made with several cement types, Cem. Concr. Res. 18 (1988) 687-698.

[34] E. Redaelli, M. Carsana, M. Gastaldi, F. Lollini, L. Bertolini, Electrochemical techniques for the repair of reinforced concrete suffering carbonation-induced corrosion, Corros. Rev. 29 (2011) 179-190. 